Research Council will be considering a set of criteria drawn up by a committee under Professor Geoffrey Dawes and intended for use in awarding research grants, but which is almost certain to be publicly understood as a kind of code of conduct. Neither the council nor those who may ultimately benefit from a better understanding of early human embryology can afford to be too timorous. The Warnock committee, set up in the summer by the British goverment (see Nature 29 July, p.408) has the wider responsibility of reconciling ethical issues and religious interests with the interests of people working in research. The danger that it will be stampeded by the fuss about Dr Edwards's speech into a flat prohibition of work with human embryos is probably remote. But it is to be hoped that the committee will fight shy of arbitrary distinctions between the permissible and the impermissible. People with sensible questions to ask should be allowed to ask them. Just now, there are not many. Later there will be a host.

\section{Who pays whom?}

\section{For peace on health service pay, the British \\ government will destroy its universities.}

Mrs Margaret Thatcher's British government has surprisingly taken fright that some radical proposals for reducing the cost to the public purse of certain social services have been leaked to The Economist, and is busily denying that it ever intended to take them seriously. With the army of low-paid workers in the National Health Service still disputing the government's offer of salary increases for the current year, it is understandable that the government should not wish simultaneously to fight for the notion that the health service should be financed by insurance payments from those who benefit or who may ultimately benefit. The truth (see Nature 23 September, p.287) is that the immediate need is not for a different way of paying for the health services but for a different (and better) way of running them.

One of the adventitious casualties of the disowning by the government of the discussion document on public spending produced by the Central Policy Review Staff (the "think tank") is the reasoned case which it contained for a different way of paying for British universities, one in which British students at British universities would not be paid maintenance grants (means-tested according to parental income) as at present, but would be invited to compete for a large number of scholarships each year. The calculation that it would be electorally dangerous to raise the possibility of financing the health services differently so soon before an election may be accurate, but is it necessary that prudence (not easily distinguished from a lack of courage) should extend so far?

By the end of this week, even Oxbridge will have reassembled for the new academic year, and British universities will be faced with an unprecedented challenge to their pretence of independence - there will be students whom the universities could teach and who are prepared to pay the costs involved but who nevertheless cannot be taken in because the universities have been given quotas of students whom they may educate, and dare not exceed them for fear of incurring financial penalties in years to come. The arrangement, forced on the University Grants Committee by the government, which has failed to find a way of containing the sums of money local authorities are required by existing law to pay to and on behalf of students, is inequitable but also iniquitous. If it persists for long, British universities will be sub-departments of government departments before they know where they are. Should they not rescue Mrs Thatcher from the embarrassment she has been caused by one of her cabinet colleagues' decision to spill the beans about the health services proposals at the wrong time? What, in other words, do the vicechancellors of British universities have to say about the proposals now in abeyance? They will respond that they are too busy, now that the new term has begun. (In between, of course, they are on vacation.) Briefly, (they say), it is not that they do not have the inclination to fight for the institutions that employ them, but that they cannot spare the time. A pity, history will think.

\section{Zen and US schools}

"Quality. . you know what it is, yet you don't know what it is. But that's self-contradictory. But some things are better than others, that is, they have more quality. But when you try to say what quality is, apart from the things that have it, it all goes poof. . . there's nothing to talk about. . . but for all practical purposes it really does exist. What else are the grades based on? Why else would people pay fortunes for some things and throw others on the trash pile?"

A committee of eminent of US academics with the daunting title of the Conference Board of Associated Research Councils uses this quotation from Robert M. Persig's Zen and the Art of Motorcycle Maintenance to express its quandary after taking on the task of rating graduate departments in the United States. The first part of its five-volume study has just been published, covering chemistry, computer science, geoscience, mathematics, physics and statistics/biostatistics programmes. It avoids an overall rating - 1, 2, 3 - for which earlier studies have been criticized. Instead, it attempts a subtle definition worthy of Zen's convoluted introspection. While the study may thus avoid criticism - and be more useful than its predecessors - it may have gone so far in quantifying quality that, in Zen's phrase, "it all goes poof"'.

The study uses some standard indicators that any professor or grants administrator would agree are useful, such as faculty reputation and the effectiveness of a department in educating students. There is also a pair of interesting new indicators: the number of articles published (normalized for department and faculty size) and "overall influence" of the articles (if they appeared in journals such as Nature). Other indicators used tend to correlate with these rankings on reputation, such as programme size and the number of years from a graduate student's enrolment to receipt of a degree. Then there are library size, the proportion of graduate students with federal grants or fellowships, the number of faculty members with federal support and the proportion of graduates with firm job plans after graduation. There are sixteen indicators altogether, but the study group declines to lump them into an overall score for each department. The result is a volume the size of a telephone directory that shows all sixteen indicators for the 596 departments surveyed. Since the reader must decide which indicator to use in determining a ranking, he bears the burden of deciding "what is quality"'.

The result is an embarrassment of riches for users of the study, who include students deciding where to apply, agencies deciding grant awards and faculty members on the move (not to mention the social scientists who have made a cottage industry out of studying such studies). Predictably, the best departments in the fields covered are the two coasts - Stanford University, the California Institute of Technology and the University of California at Berkeley sweep the board on the West coast (not always in that order), while Massachusetts Institute of Technology and Harvard University are on top in the east. Yet even there, some departments do less well in educating students. Other schools are given ample chance to shine: Cornell is near the top in physics and gets high marks for having greatly improved its geosciences departments in the past five years.

So how seriously will these studies be regarded? By the committee's own admission, there were serious internal arguments about whether it was taking the relativistic approach too far. A dissenting view by three members tellingly criticizes several indicators, especially that which rates departments according to the number of graduates planning to work in institutions that grant PhDs. These days, when so many of the best graduates are going to industry, this measure hardly indicates quality. As a whole, the committee suggested that future studies should also use non-academics as evaluators of departmental worth. Thus, it seems, the values of the committee are in the process of change. This may explain why it found the answer to the question "What is quality?" so elusive. 